\title{
Sisterhood AND Sibling RivalRy In ROMAN SOCIETY
}

\section{PAULINE Ripat}

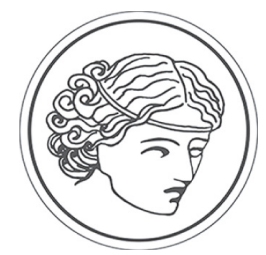

\section{ABSTRACT/RÉSUMÉ}

Roman evidence for relations between sisters is thin, but what there is suggests that sororal relations were, like all familial relations, subject to ideals of behaviour that might be difficult for individuals to attain. Ideally, sisters, as almost interchangeable versions of each other, were supposed to offer each other unstinting and selfless support, particularly in the context of childrearing. However, these ideals could be difficult to achieve in light of the habit of assessing a woman's worth with reference to her ability to produce children and the reality of high child mortality rates; envious feelings between sisters might take over. Rituals on the dies lustricus and the annual rites of the Matralia may have addressed the incompatibility of the ideals that framed female existence.

Il n'y a pas beaucoup de preuves sur les relations entre les sœurs romaines, mais ce qui existe suggère que les relations sororales étaient, comme toutes les relations familiales, soumises à des idéaux de comportement qui pouvaient être difficiles à atteindre pour les individus. Idéalement, les sœurs, en tant que versions presque interchangeables les unes des autres, étaient censées s'offrir mutuellement un soutien désintéressé et sans réserve, en particulier dans le contexte de l'éducation des enfants. Cependant, ces idéaux pouvaient être difficiles à réaliser en raison de l'habitude d'évaluer la valeur d'une femme par rapport à sa fécondité en combinaison avec des taux élevés de mortalité infantile, et la jalousie entre soeurs pouvait entrer en jeu. Les rituels sur le dies lustricus et les rites annuels de Matralia ont peut-être abordé l'incompatibilité des idéaux qui influençaient l'éxperience féminine.

\section{INTRODUCTION}

"When a white booby or black eagle nestling pummels its younger brother or sister into a bloody, pulpy mass, is this a dysfunctional family?" asks Scott Forbes in A Natural History of Families. ${ }^{1}$ No, it is not, Forbes argues; so intense is sibling rivalry in the animal world that it often leads to murder, so natural is it that murder often occurs beneath the unconcerned gaze of the parents.

${ }^{1}$ Forbes 2005: 197. 
Even humans are implicated: many single births are conceived as twins, each in different ways succumbing in utero to the natural impulse for supremacy signalled by survival. ${ }^{2}$ The tendency of human siblings to carry on competition ex utero, familiar now, was also recognized in antiquity. This was despite ubiquitous ideals of familial harmony and so integrity—or perhaps these ideals existed because of the difficulty of achieving them. ${ }^{3}$ The Romans even grounded their legends of the foundation of Rome in sibling competition. ${ }^{4}$ The displacement of King Numitor by his younger brother Amulius (whose name recalls aemulus, "envious rival") back in Alba Longa serves as a prequel to the main event, the quarrel between the twins Romulus and Remus. Who is to be king of their new city? In contrast to the case of their grandfather and great-uncle, birth order cannot be used to justify priority. Cooperating to the extent that they allow the gods to decide, the boys soon dissolve into squabbles when Remus receives a sign of six vultures first and Romulus receives a sign of 12 vultures second. This kind of conundrum has wearied parental ears for millennia, yet neither Rhea Silvia nor Mars is around to send the boys back to the Lupercal until they can work it out, and Remus ends up dead. ${ }^{5}$

With such beginnings, it is no surprise that brothers behaving both well and badly toward each other figure prominently in Roman history and legend. It is easy to remind ourselves, for example, of the solidarity of the Curiatii on the one hand and the Horatii on the other, of Marcus Cicero's careful tutelage of Quintus, of Catullus' grief over his brother's death, of Domitian's petulant jealousy of Titus, of Marcus Aurelius' blind devotion to the feckless Lucius Verus, of Caracalla's extermination of Geta. But what about the mutual behaviour of sisters? With regards to Greek society, Mark Golden remarks that "unfortunately, little can be said about the relations of sisters," and similarly, relatively little has been said about sisters in Roman society, ${ }^{6}$ presumably because sisters' relationships with each other fall victim

${ }^{2}$ Forbes 2005: 139-144.

3 E.g., Dixon 1999: 151: "The common ideological stress on public shows of family solidarity and specific cultural elaborations (such as pietas and concordia) on harmony, love, and duty stem from a general awareness that siblings, in-laws, and spouses have conflicting interests which continually threaten the economic and other needs for the family to operate as a unit."

${ }^{4}$ See Neel 2015.

${ }^{5}$ Livy 1.3-7; Florus 1.1.6; Servius ad Verg. Aen. 1.273. See Wiseman 1995: 1-17 for variations in different authors, not all of which emphasize discord or rivalry.

${ }^{6}$ Golden 2015: 114. Notable for Roman society is Hallett's 1985 study of women in the Roman family, which treats sisters' mutual relations and addresses maternal aunts (see especially 180-189). Bettini 1991 considers sisterhood in the context of aunthood, looking at maternal and paternal aunts in separate chapters. See also Saller 1997 for in-depth consideration of these and other extended kin. Dasen 2005 includes consideration of mythological female twins, Manioti's 2012 dissertation provides sensitive treatment of sisters in Latin epic, and McClain 1998 provides a brief exploration of sisters in Livy. But representative of the general trend is the single 
to the evidentiary silence that surrounds all relationships that do not feature a male as one of the primary partners. ${ }^{7}$ Yet sisters certainly had mutual relationships, and historical disinclination to record much about them should not imply the insignificance of sisterhood to sisters themselves. Careful scrutiny of thinly scattered evidence makes it possible to say at least something about sisters in Roman society. Specifically, it is possible to discern ideals of similarity and mutual support among sisters, and further, to identify marriage and aunthood as contexts in which these ideals ought especially to be displayed. More interestingly, it is possible to detect recognition that marriage and childbearing could make selfless support much more difficult to display than selfish envy, and we can glimpse the most extreme expected endpoint of envious competitiveness: death. But unlike the consequences of male sibling rivalry, death did not menace the sisters themselves, but their children.

\section{LIKE SISTERS: SORORITY AND SIMILARITY}

Rivalry requires as a premise a degree of equality. Competitors must begin at the same starting line. Otherwise, there is not competition but hierarchy, and a shift in power is not a contest but a revolution. ${ }^{8}$ Siblings present as prototypical rivals struggling with each other over limited resources (food, space, time, money) whose distribution is perceived to be, or in fact is, connected to the relative degree of parental esteem or more widely bestowed social approbation. ${ }^{9}$ In antiquity, notwithstanding individual examples of parental affection for daughters (such as Cicero's devotion to his daughter Tullia), sons were generally invested with greater social value than daughters. $^{10}$ This is attested by incidence of funerary commemoration and perhaps by habits that might have seen more girls than boys exposed, but also by anecdotal evidence that appears to sneak mainly boys into the birthing room to provide a happy result for faked pregnancies." The value of sons relative

reference to "sisters" in the index of the recent A Companion to Families in the Greek and Roman Worlds, edited by Beryl Rawson (2011); there are no references to aunts.

${ }^{7}$ Hallett (1985: 181) suggests that habits of exposure might have meant that relatively few girls would have had sisters than brothers. See Harder 2008 on sisters and brothers. Dasen (2005: 155) notes the relative paucity of female twins in mythology in comparison with male twins.

${ }^{8}$ Foster 1972: 170-171, 185; Smith and Kim 2007: 48-50.

9 See Foster 1965: 298-299 for anthropological assessments of some recent societies where the concept of finite maternal love is so strong that it figures in medical explanations of children's ill health: children are poisoned by their siblings' envy.

10 Späth 2010 advances the interesting argument that Cicero's treatment of his daughter and son, though influenced by gender, is less indicative of affection than of Cicero's desire, as a novus homo, to establish his family's tradition.

${ }^{11}$ On funerary commemoration, see Mander 2013: Chapter 2; on exposure of girls, see Dyson 2011: 437; Golden 2015: 81. Supposition of children: see, e.g., Hor. Epod. 17.50-52; cf. Plaut. Truc. 389-409, where either a boy or a girl is said to be acceptable 
to daughters is reflected in the cultural practice of differentiating boys from each other by assigning to each a different praenomen, although the name itself was predetermined by family structure and birth order. It is difficult to discern even this minimal attempt at individualization when it came to daughters. For example, in the Republic, a Roman daughter generally received the feminine form of her father's gentile name, and so the same name as all of her sisters. ${ }^{12}$ Though practice might seek to differentiate daughters by the assignment of ordinal rankings as names (e.g., Tertia, Quarta) or adjectives or endings to suggest who arrived first and who arrived next (e.g., Maior, Minor), the habit has rendered sisters in historical memory akin to Augustan marble reliefs of piglets suckling next to their littermates: interchangeable. ${ }^{13}$ Thus does William C. McDermott, in a rare treatment of sisters, seek to untangle which Clodia did what and with whom, and to trace where the confusion came in for posterity. ${ }^{14}$

It does not appear that failure to individualize daughters was an absent-minded oversight of social practice. On the contrary, and although experience surely provided proof that sisters were not in fact exactly alike, there is evidence to suggest that sisters were expected to mirror each other. For example, Livy must report to his audience the apparently surprising fact that King Tullus' two daughters, the Tulliae, had quite different personalities (ipsae longe dispares moribus, 1.46). The term soror could be used metaphorically in literature to suggest gradations or overlapping components, such as when Horace (Carm. 1.24.6-7) identifies Justice's sister as solid Loyalty, incorrupta Fides-a term that described idealized sisterhood itself. Soror therefore suggested an affinity of character, and when Apuleius (Met. 1.12-13) has the witches Meroe and Panthia address each other as soror, he surely means his readers to understand that it is not only their advanced age (they are mulieres duae altioris aetatis) that has made them indistinguishable, but also their moral fibres, which have been cut from the same cloth. Biological sisters could even function in stereo in literature, as Psyche's sisters do. ${ }^{15}$ Appropriately referred to simply as altera and alia (Met. 5.9), designations reminiscent of the use of ordinals, ${ }^{16}$ they are identical to each other in their emotions and actions (Met. 4.28-5.27). While it is true that they are different from Psyche, it is notable that the only point of reference for describing

(404), but it is a boy who is brought in. See also Richlin 2014: 261 on preference for male children, as betrayed in medical advice to promote conception.

${ }^{12}$ Kajava 1994: 11; McDermott 1970: 40.

${ }^{13}$ See, e.g., Zanker 1990: 177 fig. 138.

${ }^{14}$ McDermott 1970.

15 See especially Manioti 2012: 27-118 for sisters (related by blood or emotion) functioning this way in Latin epic. Dasen (2005: 155) notes that in mythology, unlike male twins, female twins generally "forment d'ordinaire des paires inséparables, unies pour le meilleur ..."

${ }^{16}$ I am indebted to Fanny Dolansky for this observation. 
distinction is their younger sister: they were both older and less beautiful than she (Met. 4.28).

Similarity was surely prized because it suggested empathetic support. The invocation of soror functioned almost proverbially in comedy to suggest an ally or confidante, particularly in plots to deceive male relatives and associates. ${ }^{17}$ A sister could be depended upon to tell a woman what she wanted to hear, as when Anna encourages Dido to forget her dead husband and pursue Aeneas (Verg. Aen. 4.31-53); ${ }^{18}$ when things go poorly, sororal- and self-recrimination blend. As Aeneas makes preparations to depart, Dido says to her sister Anna, vides toto properari litore circum (Aen. 4.416), which we might have translated as "Anna, you see the intense activity on the shore," were it not for Servius, Vergil's ancient commentator, who encourages a tart interpretation: "Thanks a lot, Anna. See for yourself the intense activity on the shore."19 For his part, Ovid (Fast. 3.632) has Aeneas display in Italy too his characteristic insensitivity to women's feelings by asking his new wife Lavinia to treat his ex-lover Dido's sister Anna as her own sister (carae more sororis). Surely only Aeneas is surprised when the logic of sororal sameness works against Anna rather than in her favour: Lavinia perceives the sister of a rival as a rival, and Anna (acting on the warning delivered by her true sister in a dream) must escape this identity crisis by jumping out of a window (Fast. 3.639-656).

Like all female emotions, sisterly affection, and so solidarity, could range to extremes. The myth of Philomela and Procne (Met. 6.438-674) offers a cautionary tale. When Procne's husband rapes her sister Philomela and then rips out her tongue to ensure her silence, Procne, rejecting the framework of sexual rivalry her husband has invoked in favour of sororal support, ${ }^{20}$ serves him their son for dinner in vengeance. But equally monstrous was an absence of sisterly affection and loyalty. When Psyche's sisters begin to plot against her marriage, Apuleius can think of many things to call them, such as deceitful bitches (perfidae lupulae) and horrible blood-suckers (pessimae lamiae, Met. 5.11)-a concept to be discussed below - but certainly they are to be called "sisters" no longer (sorores appellare non licet, Met. 5.13; cf. sorores nomine mentientes, Met. 5.14). Striking the right balance is Seneca's aunt, sister of the grief-stricken Helvia. Who is to be Helvia's greatest source of comfort (maximum . . . solacium, Helv. 19.1) when Seneca's exile deprives her of her son? Interestingly, it is not Helvia's grandchildren, though they will bring some pleasant diversion, but rather her second self, her ever-supportive sister (18.4-6).

${ }_{17}^{17}$ Plaut. Cist. 3-5, Truc. 438; Ter. Andr. 121-136; Eun. 144-146.

${ }^{18}$ Manioti 2012: 37-45 provides a careful analysis of Dido and Anna's relationship.

19 Translations are mine unless otherwise indicated. Servius notes that Dido addresses Anna prope invidiose, quia ipsa nuptias suaserat. Of vides, he says quasi diceret: ipsa tibi crede.

${ }^{20}$ Among Philomela's last words (Met. 6.537-538) are paelex ego facta sororis, /tu geminus coniunx, hostis mihi debita Procne! On paelex, see Richlin 2014: 227. 
MORE MOM: THe MATERTERA

As the examples above suggest, there were many situations in which sisters might seek each other out for comfort or help. It is, however, in the context of childrearing that it is possible to see most consistently the ideal of sororal sameness and selfless substitution. Latin differentiated between the maternal aunt, the matertera, a stuttered repetition of mater, and the paternal aunt, the amita. ${ }^{21}$ The legal and social locations of materterae do not initially strike one as particularly different from amitae-a nephew could marry neither, ${ }^{22}$ and both are in evidence caring for the children of their dead siblings. ${ }^{23}$ However, Pliny suggests that the two were not interchangeable in terms of their points of reference and the expected tenor of their attitudes. When all is going well with his young wife Calpurnia, Pliny compliments Calpurnia Hispulla for being more than an amita to her-not just a paternal aunt, she has taken a truly paternal interest in her niece (nec tantum amitae ei adfectum verum etiam patris amissi repraesentes, Ep. 4.19.1). But when misfortune strikes in the form of miscarriage, Pliny does not appeal to Calpurnia Hispulla as an amita-emotional trauma of this type is apparently not the time to display amitae adfectum-and he instead effectively renders her an honorary matertera by invoking her maternal affection (materna indulgentia, Ep. 8.11.1) for her brother's daughter. ${ }^{24}$ A famous story told by both Cicero (Div. 1.104) and Valerius Maximus (1.5.4) similarly suggests that materterae were better suited to shadowing maternal responsibilities. The matertera Caecilia Metella was maternally matchmaking for her niece. ${ }^{25}$ While the pair engaged in the custom of awaiting the appearance of a marital omen at a shrine, the niece grew

${ }^{21}$ Note Auson. Parentalia 6 for a matertera honoured as vice matris. See Bettini 1991: 67-99 on the matertera and the ideal of maternal duplication. He notes (67) Festus' (121L) derivation of the term as quasi mater altera, "almost another mother." Saller (1997: 18-32) rejects differentiation between nieces' and nephews' experience of their materterae and amitae. I argue that enshrined expectations of each were different, regardless of individual examples of experience to the contrary. See n. 24.

${ }^{22}$ Gai. Inst. 1.62; cf. Dig. 38.10.10.4. Treggiari 1991: 38 notes that men were also barred from marrying their sisters' daughters, granddaughters, or greatgranddaughters.

${ }^{23}$ Bettini 1991: 72-75 for inscriptional evidence; see also UPZ 1.59 (Ptolemaic), SB 14.11881 (fourth century AD); cf. P. Bour. 25 (fourth century AD).

${ }^{24}$ See Bettini 1991: 100-106 on amitae and the "paternal characterization of this aunt" in literature, in contrast to the affection expected from a mother's siblings. Saller (1997: 24-25) takes Plin. Ep. 4.19.1 as demonstration that a paternal aunt might be affectionate too. This is undeniable. My point here is rather that different emotional contexts were generically considered more suited to some positions than to others.

${ }^{25}$ An activity regularly undertaken by mothers; see Treggiari 1991: 125-127. Note, however, Bettini 1991: 88-92 on marriage omens and the possibility that omenseeking was a prerogative of the matertera; Saller (1997: 29) instead identifies the shrine as the "customary" part of the ritual, not the aunt. 
weary of standing and asked her aunt if she might have her chair, which Caecilia happily ceded. When Caecilia died soon after, the niece married her matertera's widower: in urban legend, interchangeability could even skip generations.

But materterae were not expected to display maternal affection toward nephews and nieces only when their sisters were dead. On the contrary, and in the best-case scenario, materterae would be present to care for the children of still living sisters. ${ }^{26}$ Seneca's matertera's ability to function as Helvia's supportive doublet is proven by her past actions. She carried Seneca as an infant to Rome in her arms, she nursed him through lengthy illness, and she even overcame her natural shyness to support his political ambitions (Helv. 19.2): Seneca's matertera has been an excellent mater, and so is a sterling soror to Helvia. Quasi-sisters were held to the same standard, if the claims of Apuleius' fictional Byrrhena can be taken as evidence. She tells Lucius that she had raised him with her own hands-and why not? She and his mother were close relatives and milk-mates (ego te, o Luci, meis istis manibus educavi-quidni? - parentis tuae non modo sanguinis, verum alimoniarum etiam socia, Met. 2.3). ${ }^{27}$ Later in the novel, Psyche's sisters, discovering that Psyche is pregnant, declare their feigned joy in the manner that they know is expected of them-how delighted they are at the prospect of nurturing her baby! (o nos beatas, quas infantis aurei nutrimenta laetabunt! Met. 5.15) — and their true displeasure at Psyche's pregnancy is surely to be understood as sinisterly perverse. Murderous materterae are as horrifying as murderous mothers, and special dread grows when the pleas of Pentheus, about to be torn to pieces, fall upon the deaf ears of his matertera Autonoë (Ov. Met. 3.719). ${ }^{28}$

Ideals of sisterly behaviour in the context of aunthood contrast sharply with the stereotypes of other quasi-mothers, such as the difficult motherin-law and the notoriously hostile stepmother (even a good stepmother takes a toll on a child, says Seneca: nulli tamen non magno constitit etiam bona noverca, Helv. 2.4). ${ }^{29}$ In addition to sundry other unpleasant relatives, Ovid says evil stepmothers and terrible mothers-in-law are unwelcome at

${ }^{26}$ Perhaps this is why a cousin on the mother's side receives particular recognition with the term sobrinus/a; see Hallett 1985: 186. Note that the Curiatii and Horatii were said (Dion. Hal. Ant. Rom. 3.15.2) to be cousins on their mothers' side, a detail that surely added particular pathos for the ancient audience; see Bettini 1991: 69. Hallett (1985: 183) suggests that sisters "would seem to fit Tacitus' description at Dialogus 28 of the propinquae who assisted a Roman matron in childbearing."

${ }^{27}$ See Dasen 2011: 309 on the bonding power of a shared nurse.

${ }^{28}$ For a further example of a matertera-nephew relationship within the ideals of maternal mirroring, see Bettini 1991: 92-99 on Amata and Turnus.

${ }^{29}$ For conflict between mothers- and daughters-in-law, see Huebner 2013: 142143 and, e.g., SB 3.6264; P. Petaus 29. 
the Caristia, the celebration of the living family that came on the heels of the Parentalia, the celebration of the familial dead (Fast. 2.617-639). Ovid invokes Ino as an example of the kind of stepmother who should keep her distance, for she had attempted to murder her stepchildren Phrixus and Helle (Fast. 2.623-626; 3.849-876). But Ino the evil stepmother is elsewhere Ino the devoted matertera who tenderly nurses her orphaned nephew Bacchus upon the immolation of her sister Semele (Ov. Met. 3.313-314). It is in fact her particular pride in her nephew (Ov. Met. 4.416-422; cf. Serv. ap. Aen. 5.241) that causes Juno, out of continued jealousy of the dead Semele, to drive Ino to madness and to murder her own beloved children (Ov. Met. 4.512-530; Fast. 6.485-498). In Ino we see the familiar ancient expectation that female behaviour should conform to the position inhabited regardless of personality: novercae are cruel, materterae are loving. Also familiar is the recognition that expected behaviour could be perverted when uncontrollable emotions intervene: Ino, driven mad, kills her own children. But it is important to observe that the misfortunes visited upon children can appear as the collateral damage of women's hostility toward each other, hostility that is connected to childbearing. $3^{\circ}$

The spectre of feminine hostility is interesting in the context of sisters functioning within the ideological framework of sameness, solidarity, and closeness, particularly as they grow up to marry and become mothers. It is here that suspicion arises that the ideals of female behaviour first as sisters and second as wives and mothers might be, for some, incompatible. An excellent sister would single-mindedly strive to maintain the line of similarity by failing to make herself especially noticed in her own right in any circumstance, something the virtuous sister of Helvia manages to achieve (Sen. Helv. 19.4-7). An ideal sister would also continue to be supportive when a sister's fortune was perceived to be better than her own, something the blameless Afronia chose to do when her sister became their mother's sole heir (Val. Max. 7.8.2), and something the ferox Tullia of Servius Tullus' daughters cannot do when the docile Tullia marries the husband better suited to the first's own cupiditas and ambitio (Livy 1.46). ${ }^{31}$ Though the gentle Tullia ends up dead-legend likes the results of rivalry to be unequivocalwe must suspect that real human experience and emotions allowed for a wide and complicated spectrum of responses between the poles of selfless support and murderous hatred when sororal sameness was upset by changing circumstances. Among the possible emotions was certainly envy, a destructive emotion so difficult to control that it was often conceded to be unintentional,

30 Foster (1972: 174) notes that in societies that subscribe to the evil eye (on which, see further below), children are often seen as the "most vulnerable spot" of the real target of hostility, the parent.

${ }^{31}$ On Livy's characterization of Tullia as an un-Roman female in her roles as daughter, wife, and sister, see Hallett 1985: 189. 
so antisocial that it required concealment, and whose very cradle was sudden disparity in the pressurized context of proclaimed similarity. ${ }^{32}$

\section{Breaking the TIE: MarRiage AND ChILDREN}

Marriage and children could threaten equality among sisters, leaving the ideal of similarity a shell whose relevance remained only in its function as a frame of reference for expected behaviour. Although dowry size could vary quite widely between wealthy and poor families, ${ }^{33}$ the dangers of uneven fortunes among sisters were tacitly recognized in attempts to equalize dowries among daughters (e.g., Polyb. 31.9.27). ${ }^{34}$ But also present was the sentiment that the amount of a dowry ought to be determined according to the husband's lifestyle, as the dowry should allow a wife to keep up with her partner (e.g., Plin. Ep. 6.32). Similar sisters could not all marry the same man, and not all men were equal in wealth, family, habits, or social stature. History, fiction and myth provide some extreme examples of disparate grooms. Livy (6.34.5-10) recounts the story of Fabia Maior and Fabia Minor, married to a celebrated magistrate and a good-hearted plebeian, respectively. Fabia Minor attempts to conceal her envy of Maior's marriage and so preserve her pietas, but her perspicacious father draws the truth from her, and soothes her with assurances that her stalwart husband will soon achieve equal esteem. ${ }^{35}$

Psyche's sisters provide a fictional counterpart with a less happy denouement. Though untroubled by the fact of their inferior looks (Apul. Met. 4.28), they cannot entertain the thought of Psyche's superior marriage-in this case, to a god-without succumbing to envy (5.9-10). Psyche attempts to share her good fortune by loading gifts upon her sisters. Anthropologists note that this sort of act, the offering of a "sop," is commonly deployed to dispel envy in situations where equality is threatened by one person's prosperity ${ }^{36}$ But the disparity cannot be equalized and Psyche's sisters explain

${ }^{32}$ Livy 6.34.7 notes that one least wishes to be surpassed by those closest (a proximis quisque minime anteiri volt). See also Cic. Tusc. 4.12.27-28; Johnston 1999: 197198. Smith and Kim 2007: 48: "Envy violates social conventions that usually require supportive rather than competitive, begrudging reactions to another person's success." See also Foster 1965: passim. On the place of envy within the constellation of emotions recognized by the Greeks and the Romans, see Kaster 2005 and Konstan 2006.

33 Hor. Ep. 1.17.46-47 suggests that even the very poor were expected to have some kind of dowry.

34 Treggiari 1991: 324-325; Saller 1994: 202-224; for Greek society, see Golden 2015: 114-115.

${ }^{35}$ McClain (1998) analyzes sororal dynamics in this episode within the context of other sisterly relations in Livy's history, observing (17) that Fabia Minor is to be understood not as jealous, but as pia. But it is consistent with McClain's arguments to note that it is Fabia Minor's successful struggle to ensure that the improper emotion did not gain ascendancy that deserves emphasis; envy was not absent.

${ }^{36}$ See Foster et al. 1972: 177-182 for examples. 
away their growing hostility to their sister as her fault: they tell themselves that Psyche has been stingy and so has treated them contemptuously, and they promise each other that they will make Psyche recall that they are her elder sisters, not her slaves (sciet se non ancillas, sed sorores habere maiores, 5.10). ${ }^{37}$ In the same vein, Aglauros cannot be mollified by Mercury's promise that she will be known as matertera to his children should she allow him access to her sister Herse (Ov. Met. 2.746), and envy rots her and turns her to stone as she obsessively dwells on her sister's better fortune..$^{38}$

But if dissimilar marital partners and the resulting dissimilarity of experience were causes for envy among sisters, the prospect of children resulting from these disparate unions was perhaps for some even more so. One of Psyche's sisters threatens to hang herself should Psyche become known as the mother of a god (certe si divini puelli-quod absit-haec mater audierit, statim me laqueo nexili suspendeam, Apul. Met. 5.16), and we have just seen Aglauros' response to the same suggestion. Notwithstanding their fictional nature, we might ask why Aglauros and Psyche's sisters are unable to tolerate a situation that brings Ino, also the matertera of a child with divine paternity, satisfaction. We might suspect that it is because Ino as matertera had no mater to contend with: Semele was dead, and the glory to be derived from nurturing the child Bacchus was undivided.

In real life, the enmity that Augustus' sister Octavia developed for her sister-in-law Livia presents a corollary that suggests that real women might resent another whose resplendent maternity cast them in a dull shadow. Seneca reports that when Octavia's son Marcellus died, she never recovered from the loss. But instead of hating Tiberius as we might have expected, since it was he who filled the previously Marcellus-shaped position of pre-eminence, Octavia is alleged to have nurtured hatred of all mothers and of Livia, Tiberius' mother and her sister-in-law, in particular (oderat omnes matres et in Liviam maxime furebat, quia videbatur ad illius filium transisse sibi promissa felicitas [Marc. 2.4, "She hated all mothers and was especially hostile to Livia, since the happiness promised to herself seemed to have passed to her son"]). Significantly, to make Octavia's enmity understandable, Seneca does not need to reference the rumours that Livia had angled for Marcellus' demise with the liberal distribution of poison; ${ }^{39}$ ceding the position of Mother of the Future Princeps was explanation enough.

${ }^{37}$ Note the observations of psychologists Smith and Kim (2007: 48): "invidious resentment occurs when the advantage is painful but fair by . . . objective standards," and (56) "people feeling envy will tend to find ways to justify their hostility."

${ }^{38}$ Manioti 2012: 167-168 provides discussion of the descriptive parallels between the tales of the Fabiae and of Aglauros and Herse.

39 Dio Cass. 53.33.4. Livia was also rumoured to have had a hand in the deaths of Gaius (Tac. Ann. 1.3, Dio Cass. 55.10.9), Agrippa Postumus (Tac. Ann. 1.6, Dio Cass. 57.3.6), and Augustus (Dio Cass. 56.30.2). 
Most women did not have children fathered by gods or adopted by emperors, but Octavia's tale of loss and so her sense of "losing" to her equals - and so competitors-is surely relevant to our understanding of the complex emotional threads from which sisters' relationships were woven. The importance for Roman women of having children, living children, cannot be underestimated. In a society that placed great weight on the reflective power of external markers, children were the major index of a woman's social value. Valerius Maximus comments that children are women's greatest ornaments (maxima ornamenta esse matronis liberos, 4.4 praef.), a proverbial idea communicated by Cornelia's legendary pronouncement that her jewels were her brood of Gracchuli. The presence or absence of children served to demonstrate the kind of woman a woman was. The woman who was childless by nature was divorceable; ${ }^{40}$ the woman who was childless by choice was vain (e.g., Ov. Am. 2.13-14). Horace slanders Canidia by casting suspicion upon her claim to have birthed a child at all (Epod. 17.50-52). Latin poetry of all genres advertises the absence of children as heirs as the only reason that anyone would ever seek the company of an elderly widow. ${ }^{41}$ Anus, a term of disdain and pity, often applied specifically to women who were bereft of male children and too old to have any more. ${ }^{42}$

The importance of childbearing in the maintenance of a woman's social persona is also evident in the determination to advertise maternity even when children had died. ${ }^{43}$ Some women whom death had deprived of their sons never took off mourning clothes. Seneca (Helv. 16.2, 6) censures this habit in favour of the spirit shown by Cornelia: bereft of her sons, she hushed her weeping consolers with the statement that she would not have her fortune pitied, because fortune had made her the mother of the Gracchi in the first place. For both the eternally mourning mother and Cornelia, however, children serve as the major anchor of their identity.

Children recognized their ability to bestow social value on their mothers. We can see this in Seneca's approving account of a famous incident whose details are otherwise lost to us: remember that son, says Seneca, who defended his mother in a public assembly with the question "how dare you malign the woman who gave birth to me?" (Helv. 16.6, Tu matri meae male dicas, quae me peperit?). In fact, children's ability to invest women with reflected social value was so powerful that it extended even to nurses. In an early second-century AD letter from Egypt, ${ }^{44}$ a pair of parents solicit a woman of lower social class to be a nurse for their baby. "Sister," they appropriately

$4^{40}$ Treggiari 1991: 462, and, e.g., ILS 8393 (the so-called laudatio Turiae), section 31; on this see Hallett 1985: 182.

${ }^{41}$ E.g., Hor. Ep. 1.1.77-78; Ov. Ars am. 2.271-272; Mart. 2.26; Priapeia 57.

${ }^{42}$ Rosivach 1994.

43 Those who had survived infancy, that is; see Sigismund Nielsen, this volume.

${ }_{44}$ On this letter and the use of "sister" as a form of address for women unrelated by blood, see Bagnall and Cribiore 2006: 86-87 and 359-360. 
address her, "if you decide to be a nurse, you are going to find higher wages, because it is a freeborn child, and your fulfillment, and you are going to find parents ... for a freeborn child is one thing but a slave is another" (P. Mich.

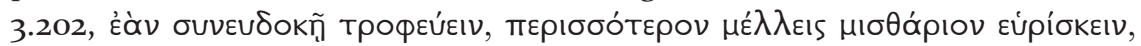

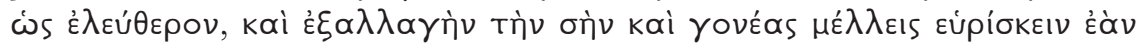

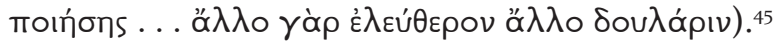

Having children-living children-was therefore not without a competitive aspect. The myth of Niobe and Latona as told by Ovid (Met. 6.152-312) presents this in the baldest terms. Which of them, each a mother for a long time already, deserves to be champion in the contest of procreation? Niobe, proud of her record of 14 living sons and daughters, is smugly confident that she will never be orba, bereft of children (tutam me copia fecit, she says, 6.193). Significantly, in her good fortune, she is the envy of her intimates (invidiosa suis 6.276). Niobe points out that Latona has produced just two children, a dangerously feeble number: Latona is seven times closer to childlessness than she is herself $(6.197-200)$. But what Latona lacks in quantity she makes up in quality, since her children are the twins Apollo and Artemis. Latona bids them to defend their mother's honour in the face of the insult she has received: "she called me bereft of children!" (me . . . orbam dixit! 6.202-203). Latona's children are quick to obey and Niobe's seven sons soon bleed out their lifeblood. But Niobe is not willing to give up yet, as she still has seven daughters. "Eat my grief, cruel Latona!" she taunts. "Even after so many deaths, I win!" (Pascere, crudelis, nostro, Latona, dolore ... post tot quoque funera vinco, 6.280-285). But not for long. When all of her daughters succumb to invisible wounds that waste their strength, Latona pulls into the lead in the competition of both quantity and quality, and Niobe has lost.

Niobe's children are killed by divinities in a welter of insult, envy, and competition, but shockingly high rates of child mortality could quickly bereave a Roman mother of her children-and so of her social standing and future support, leaving her, in the best-case scenario, simply a spare maternal figure to nieces and nephews upon whom she, as orba, might become increasingly dependent. ${ }^{46}$ Such reversals of fortune might have been easier to bear were they evenly distributed, but the death of children obeyed no quota per mother, and the commonness of children's death could not explain why

45 Trans. Bagnall and Cribiore 2006. On the material and legal benefits that a nursling might eventually provide a nurse, see Bradley 1991: 13-36; Dasen 2011: 309.

${ }^{46}$ For the vulnerability of the poor and aged population and dependence upon children, see Parkin 2011: 287-288 and Evans-Grubbs 2011: 383, with references. Huebner 2013: 171-172 addresses the possibility of nieces and nephews caring for elderly, childless relatives. Note that Auson. Parentalia 6 honours Ausonius' childless matertera. See lines 11-12 in particular: haec, quia uti mater monitis et amore fovebas, / supremis reddo filius exequiis. 
one woman's child died when another's did not. ${ }^{47}$ A Coptic letter (O. Mon. Epiph. 194, sixth-eighth century AD) survives from a mother seeking the advice of a church leader: she can bear children, but they all die; perhaps she has been doing something wrong? ${ }^{48}$ This mother assumes the fault for her misfortunes lies with herself, but many of her earlier counterparts, it seems, sought explanation in the attitudes of others for their hardships. Plutarch (Mor. 1046b-c) notes as an unlovely human trait the desire for superiority through the diminishment of others, and envy in particular was felt to be an emotion with agency to equalize bad fortune. ${ }^{49}$

Envy as the instrument of equalization had explicit currency in the context of motherhood and child mortality in the figure of Lamia, a childkilling demon adopted by the Romans from the Greek array of child-killing demons..$^{5^{\circ}}$ Unlike, say, the child-killing demon Gello, who was said to have once been a girl who had died before being able to have children, ${ }^{51}$ Lamia was said to have been a bereaved mother, and so had a rationalizing mythology that resonated particularly with still-living orbae. Equally relevant is the consequence of Lamia's misfortune: envy of other mothers, an envy that drove her to kill their children (Diod. Sic. 20.41.3-5). Lamia's name is related to the Greek word for "gullet" (laimos), and Horace (Ars P. 340) attests that the Romans too conceived of her as "devouring" children: ${ }^{52}$ don't tax your audience's credulity, he advises would-be dramatists, by pulling a live boy out of a Lamia's stomach (neu pransae Lamiae vivum puerum extrahat alvo). But there is more than one way that envy might eat a child. While the presentation of personified envy eating one whole might seem ridiculous to Horace's imagined audience of critical Romans, the idea of consuming a child's strength unto death through envious feelings was not. Envy, which could attack a victim's body through the invisible avenues of sight and breath, could corrupt health like poison; ${ }^{33}$ when Ovid (Met. 2.768-770) has Minerva visit Envy (Invidia) in her squalid, rotting home, she is right in the middle of a favourite repast of venomous serpents. Children's tender bodies were considered particularly susceptible to the invasive forces of envy, an idea surely spurred on by the difficulty of keeping them alive and witnessed

${ }_{47}$ Smith and Kim (2007: 50-51) note that the perceived inability to have what is envied, along with the fantasy of having it, fosters the elements of envy.

${ }^{48}$ Bagnall and Cribiore 2006: 247.

${ }^{49}$ E.g., Cic. Orat. 2.51.208; Fam. 3.10.1, 10; see also Foster 1972: 168; Johnston 1999: 190; Smith and Kim 2007: 46, 52.

$5^{\circ}$ On the full array, see Johnston 1999: 161-199 and Patera 2014.

${ }^{51}$ Johnston 1999: 171-172 notes that lamiae could function as a sort of category label for envious child-killing demons more generally.

${ }^{2}$ Johnston 1999: 172; Teitel Paule 2014: 753.

53 E.g., Ov. Met. 2.793-94; 798-8o2; Pliny HN 7.2.16-18; Gell. NA 9.4.7; Plut. Mor. 681E; see also Dunbabin and Dickie 1983: 11; Richlin 2014: 242. 
by the perpetual industry in protective amulets. ${ }^{54}$ Letters from Egypt indicate as a common etiquette the wish that the recipient's children be free from the evil eye, the envious look with the power to destroy. ${ }^{55}$ So identifiable with the idea of consumptive death were children that a late second-century AD curse from Rome uses the figure of a young boy as an analogy for wasting. Inscribed on a small funerary statuette showing a man and woman with a young boy between them, the curse contains the statement that the victims should similarly "know consumption between them" (quomodo isti non cumbere inter se, illi inter se consumptionem cognoscunt). ${ }^{56}$ The boy is shown wearing the bulla, the amulet that indicated his social value as freeborn and that was meant to protect him from the forces that would waste his health-a detail whose irony in this context surely points to the regularity with which the hope invested in such protective measures was disappointed.

\section{Aunt Lamia: Children, Closeness, Envy}

Lamia and her demonic associates demonstrate the desire to externalize envy, the elephant in the room whose identification through open accusation could cause permanent ruptures in relationships. ${ }^{57}$ Lamia could perform many valuable social functions, ranging from presenting a means of addressing envy without causing offence to supplying a bogeyman with which to scare children into obeying their parents. But she only makes sense as a cultural projection if maternal envy arising from children's death carried the force of widely recognized empathy and experience. Any woman bereaved of her children could presumably envy other women whose fortune was so far better, but proximity-true familiarity-was recognized as a powerful fertilizer of the emotion. This is perhaps even contained in the Latin word for envy, invidia, which could suggest scrutiny..$^{5}$ Cicero (Tusc. 3.9.20) etymologizes that the term comes from looking too closely at another's luck (nomen invidiae, quod verbum ductum est a nimis intuendo fortunam alterius).

Plutarch (Mor. 515d; cf. $516 \mathrm{f}$ and 519d) noted that the one who intentionally pried into the personal affairs of others was often prone to be both

54 Dasen 2015: 293-318.

55 E.g., PBrem. 64 (Bagnall and Cribiore 2006: 146); BGU 3.714 (Bagnall and Cribiore 2006: 179); PWürzb. 21 (Bagnall and Cribiore 2006: 279); POxy. 14.1758 (Bagnall and Cribiore 2006: 349); POxy. 6.930 (Bagnall and Cribiore 2006: 375-376); PWis. 2.74 (Bagnall and Cribiore 2006: 387-388). On the destructive powers of envy, see Ripat 2016.

${ }^{56}$ According to Kropp's (2008: 1.4.4/14) most recent reading. See also Mancini 1923: 37-39 and Della Corte 1938.

57 Johnston 1999: 196-198.

${ }^{58}$ In addition to an unwillingness to see and so to comprehend, a possibility I address at the end; these meanings need not be mutually exclusive. Envy's connection to scrutiny is strengthened by envy's close association with excessive admiration; see, e.g., Cic. Orat. 2.56.228; Verg. Ecl. 1.11; Ov. Her. 17.126. 
envious and malicious. ${ }^{59}$ Concern over physical invasiveness-not only into one's body, but intrusion into one's home-is palpable in the tale told by Statius (Theb. 1.557-626) of a lamia-like serpent-girl who slithers into women's bedrooms at night to kill newborn children and in rituals performed on the threshold to protect those inside from the ill-willed. ${ }^{60}$

What about sisters, who were explicitly already on the "inside," and whom circumstance might ignite, like Aglauros, into a brushfire of destructive envy (Ov. Met. 2.810-811)? In the actions of Psyche's envious sisters, appropriately called lamiae in the context of Psyche's pregnancy (Apul. Met. 5.11), ${ }^{61}$ we can glimpse how sisters might seek to navigate the potentially explosive situation that incompatible social values surrounding maternal identity and sisterhood sped toward. We see that proper sisterly comportment could be used to mask, but not annihilate, the envious rivalry that might arise from unequal fortune as wives and mothers. Thus do Psyche's sisters arrive at her door panting poison (anhelantes vipereum virus, 5.12), though concealing their dangerous envy beneath the cheerful and solicitous guise appropriate to their station as sisters; they have been nursing the wounds of their envy deep in their breasts (iam praecordiis penitus nutrirent invidiam, 5.7-8) ever since they discovered the incomparable nature of Psyche's husband. ${ }^{62}$

Like Psyche's sisters, women in literature are often said to conceal or nurture their true emotions unseen within their breasts or minds while arranging their overt manners to suit social expectations. ${ }^{63}$ Real women, too, were supposed to be good at this. The woman who could bury her own thoughts and desires to mirror her husband's, for example, made an excellent wife. ${ }^{64}$ But female facility at mirroring and dissimulation was problematic in women's relationships with each other. Plutarch, in a letter to his wife upon the death of their small daughter, decries the wails of condoling women, since their excessive lamentations are assaults upon his wife's struggle to maintain the emotional composure he favours (Mor. 610c-d). ${ }^{65}$ Dissimulation

59 For recognition of the same in early Christian writings, see Limberis 1991: 173-174.

${ }^{60}$ For the connections between the serpent-faced girl and lamiae, see Resnick and Kitchell 2007: 84. Thresholds and protective rites: e.g., Ov. Fast. 2.571-582, 6.133168; Pliny HN 28.157; Apul. Met. 3.23.

${ }^{61}$ For denial that this description is significant, see Paule 2014: 753. Felton (2013) (esp. 234-235) notes the importance of the concept of the lamia to the tale, but discusses it with reference to Cupid; McCreight (2006) identifies the consistent theme of the sisters as injurious to the health.

${ }^{62}$ Compare Smith and Kim (2007: 47), who note from anthropological and psychological research that envy, unlike longing, "is often kept secret" due to its recognized antisocial nature.

${ }_{3}^{6}$ E.g., Ov. Fast. 3.633-634; Her. 4.20; Verg. Aen. 4.1-2, 67; see also Bettini 1991: 71.

64 Treggiari 1991: 238-241; Ripat 2014: 345-347.

65 Compare Eur. Andr. 930-953, which Plutarch cites. See also Pomeroy 1999: 94-96, cf. 108, on Plutarch's agenda here. 
of true emotions, the sister of mirroring, is also present: Plutarch tells his wife to remember that these griefmongers are engaging in a mean habit

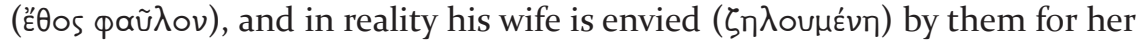
remaining children, her household, her lifestyle (611b).

A dissimulating envious neighbour was surely problematic, but a potentially dissimulating envious sister, given her special position and responsibilities, would be a crisis. The suspicion of envy was surely as destructive to a sororal relationship as its actual presence, particularly in the precarious context of children's health. It is here that ritual, which often focused on the maintenance of familial relations, addressed the corrosive emotion that social ideals and practice did not prevent. ${ }^{66}$ Ritual allowed sisters to make ostentatious displays of goodwill toward their sisters' children, specifically for the preservation of their health. These acts might perform a variety of communicative functions. ${ }^{67}$ Among them appears to have been addressing implicitly the multiple registers of fear that envy causes in humans, as identified by psychologists. ${ }^{68}$ Envy, as an admission of inferiority and hostility toward an innocent party, is a distasteful, uncomfortable, and shameful emotion: we fear being envied, we fear being thought to be envious, we fear being envious in fact. ${ }^{69}$ Ritual could bring relief, if relief were needed, for all parties. Persius describes the role a matertera might play for her nephew or niece on the dies lustricus, the ritual purification of and protection from dangerous forcesapparently including the wasting effects of envy-undertaken about a week after birth: a grandmother or matertera, herself an expert at avoiding the evil eye, uses her middle finger to wipe the baby's forehead with saliva (ecce avia aut metuens divum matertera cunis/exemit puerum frontemque atque uda labella/infami digito et lustralibus ante salivis/expiat, urentis oculos inhibere perita, 2.31-34).70 She who might have been suspected as the worst perpetrator of envy instead publicly steps into the role of protector.

This same sentiment could be ritually renewed every year during the Matralia, a festival in honour of Mater Matuta. Its associated rituals appear to have acknowledged hostile undercurrents that might arise between female relations or familiares as a function of poorly jibing social structures

${ }^{66}$ See Dolansky 2011a, 2011b for discussion of rituals focused on familial relations.

${ }^{67}$ See Dolansky 2016 on the rites of the Matralia in the context of maternal death and divorce. Richlin 2014: 231 discusses these rites as emphasizing divisions of status in the context of childrearing.

${ }^{68}$ Smith and Kim 2007: 54. As a point of modern comparison for the distastefulness of envy: of 555 character traits identified in a psychological study undertaken in 1968, "envious ranked 425th in terms of likeability."

69 Sen. Ep. 84.11 anticipates these observations with his own: "you see how wretched one is if he who is envied is also envious" (vides autem, quam miser sit, si is cui invidetur et invidet).

7o Dasen 2011: 303-304; Richlin 2014: 252-253 and 264-265. See Corbeill 2004: 49 on the digitus infamis. 
and ideals of female behaviour, including tensions between sisters. ${ }^{71}$ At the shrine of Mater Matuta, why do women pray for blessings upon their siblings' children, not their own? Plutarch asks (Quaest. Rom. 17). ${ }^{72}$ He answers his own question: possibly it is in honour of Ino's care for her nephew, or maybe it is just because it is an excellent practice ( $k \alpha^{\prime} \lambda \circ v$ है $\theta v \circ v$ ) that ensures great

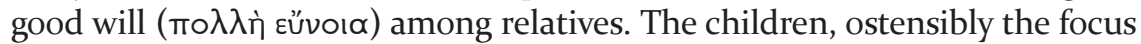
of the ritual, are actually secondary. They provide only circumstance for the real issue, relations among the parental generation that are carefully attuned to the current degree of good fortune in the form of thriving children. ${ }^{73}$ The ritual implicates a sister in her sister's maternal good fortune negatively as well as positively: the display of a sister's good wishes at the Matralia carries the unspoken recognition that these same good wishes might not otherwise be assumed to be present. ${ }^{74}$ Annual ritual might override ambiguity and undercurrents; only the passage of time and the inevitable changes to circumstance it would bring could erase them.

\section{CONCLUSION: ReAlly ENVIOUS Sisters?}

The protagonist of Elena Ferrante's recent novel, set in contemporary Italy, succumbs to envious obsession when her husband casts her aside for a much younger woman. Almost too late, the state of her crumbling surroundings pierce her preoccupied consciousness-an ill son untended, a pet dog accidentally poisoned, avenues of communication broken. "What was I?" she asks herself. "A woman worn out by four months of tension and grief; not, surely, a witch who, out of desperation, secretes a poison that can give fever to her male child, kill a domestic animal, put a telephone line out of order, ruin the mechanism of a reinforced door lock." 75 Women's envy of other women blazes a trail littered with dysfunction even still in popular consciousness, and children are felt to be at the greatest risk of suffering collateral damage.

Such projections are, as we have seen, familiar in the context of Roman society. And yet careful readers will have noticed that the foregoing invokes no direct evidence of real, indisputably envious Roman sisters. It must be conceded that no direct evidence of such exists. But we must ask ourselves what the evidence we lack would look like, and whether it is even possible that evidence of envy in any relationship could be direct. There is a notable

${ }^{71}$ See especially Dolansky 2016; Ripat 2014: 349. Bettini 1991: 76-87 provides anthropological and linguistic analysis of this ritual.

${ }^{72}$ Bettini 1991: 77 understands this ritual to involve matertera and nephews in particular; Dolansky 2016 points out that the language is ambiguous and leaves open the possibility of nieces and brothers' children too. See also Hallett 1985: 185 n. 28 for further discussion of the range of meaning of Plutarch's á $\delta \varepsilon \lambda \phi \tilde{\omega} \nu$.

${ }^{73}$ Compare Foster 1972: 174.

${ }^{74}$ Compare Foster 1972: 181 on rituals that at once acknowledge the possibility of the presence of envy and diffuse them.

75 Ferrante 2005: 118. 
disinclination in antiquity to approach envy straight on. Although envy might arise from excessive scrutiny, the envious were not to be looked at: amulets and gestures shielded targets from establishing the infectious corridor of sight through which envy might attack. Even now, just as Minerva looks away from the sight of Envy when she pays her a visit (Invidiam visaque oculos avertit, Ov. Met. 2.770), modern scholars of anthropology, psychology, psychiatry, and sociology have averted their gaze from the topic until relatively recently, despite its ubiquity and influence on human behaviour and relationships: it is just too uncomfortable..$^{76}$ In antiquity, then, envy must be detected through indirect means. It must be suspected as functions of social values and competition, it must be observed through caricatures in myth and literature, it must be interpreted as an object of ritual. All of these kinds of indirect evidence point to the recognition that envy could mar sisters' relationships, and they reflect the fear that envy's presence could diminish a sister's social persona by depriving her of critical relationships. This is not to deny that sisters might achieve the ideal of genuine, mutual, dependable empathy; it is rather to say that sisterhood, as all institutions characterized by ideals of behaviour, was equally, if tacitly, subject to the recognition that real experience and human emotion could often push the ideal beyond the scope of achievability.

\section{ACKNOWLEDGMENTS}

I thank Sinclair Bell, Fanny Dolansky, and two anonymous reviewers for their insights and comments on this paper and for pointing me to further evidence. I would also like to thank Mark Golden for his mentoring, support, and encouragement over the course of almost three decades.

\section{Department of Classics}

UNIVERSITY OF WINNIPEG

p.ripat@uwinnipeg.ca

\section{REFERENCES}

Bagnall, R. and R. Cribiore. 2006. Women's Letters from Ancient Egypt $300 B C-A D$ 8oo. Ann Arbor: University of Michigan Press.

Bettini, M. 1991. Anthropology and Roman Culture: Kinship, Time, Images of the Soul. Trans. J. Van Sickle. Baltimore/London: Johns Hopkins University Press.

Bradley, K.R. 1991. Discovering the Roman Family. Oxford: Oxford University Press.

Corbeill, A. 2004. Nature Embodied: Gesture in Ancient Rome. Princeton, NJ/Oxford: Princeton University Press.

Dasen, V. 2005. Jumeaux, jumelles dans l'Antiquité grecque et romaine. Zurich: Akanthus.

—. 2011. "Childbirth and Infancy in Antiquity," in B. Rawson (ed.), A Companion to Families in the Greek and Roman Worlds. Malden, MA: Wiley-Blackwell. 291-314. —. 2015. Le sourire d'Omphale: Maternité et petite enfance dans l'Antiquité. Rennes: Presses universitaires de Rennes.

Della Corte, M. 1938. "Sigillum-Devotio," RAAN N.S. 18: 3-13.

${ }^{76}$ See Foster 1972: 165-166; Smith and Kim 2007: 46. 
Dixon, S. 1999. "Conflict in the Roman Family," in B. Rawson and P. Weaver (eds.), The Roman Family in Italy: Status, Sentiment, Space. Oxford: Clarendon Press. 149-168.

Dolansky, F. 2011a. "Honouring the Family Dead on the Parentalia: Ceremony, Spectacle, and Memory," Phoenix 65: 125-157.

—. 2011b. "Reconsidering the Matronalia and Women's Rites," CW 104: 191-209. https://doi.org/10.1353/clw.2011.0024.

—. 2016. "Strained Relations, Gender Differences and Domestic Ideals: The Significance of Two Roman Family Festivals," in S.L. Budin and J. MacIntosh Turfa (eds.), Women in Antiquity: Real Women across the Ancient World. London/New York: Routledge. 905-914.

Dunbabin, K. and M. Dickie. 1983. "Invidia Rumpantur Pectora," JbAC 26: 7-37.

Dyson, S. 2011. "The Family and the Roman Countryside," in B. Rawson (ed.), A Companion to Families in the Greek and Roman Worlds. Malden, MA: Wiley-Blackwell. 431-444.

Evans-Grubbs, J. 2011. "Promoting pietas through Roman Law," in B. Rawson (ed.), A Companion to Families in the Greek and Roman Worlds. Malden, MA: WileyBlackwell. 377-392.

Felton, D. 2013. "Apuleius' Cupid Considered as a Lamia (Metamorphoses 5.17-18)," ICS 38: 229-244. https://doi.org/10.5406/illiclasstud.38.0229.

Ferrante, E. 2005. The Days of Abandonment. Trans. A. Goldstein. New York: Europa Editions.

Forbes, S. 2005. A Natural History of Families. Princeton, NJ: Princeton University Press.

Foster, G.M. 1965. "Peasant Society and the Image of Limited Good," American Anthropologist 67: 293-315. https://doi.org/10.1525/aa.1965.67.2.02aooo10.

Foster, G.M., R.J. Apthorpe, H.R. Bernard, B. Bock, J. Brogger, J.K. Brown, S.C. Cappannari, J. Cuisenier, R.G. D’Andrade, J. Faris, S.T. Freeman, P. Kolenda, M. MacCoby, S. D. Messing, I. Moreno-Navarro, J. Paddock, H.R. Reynolds, J.E. Ritchie, V. St. Erlich, J.S. Saviahinsky, J.D. Seddon, F.L. Utley, and B.B. Whiting. 1972. "The Anatomy of Envy: A Study in Symbolic Behavior [and Comments and Reply]," Current Anthropology 13: 165-202. https://doi.org/10.1086/201267.

Golden, M. 2015. Children and Childhood in Classical Athens, 2nd ed. Baltimore: Johns Hopkins Press.

Hallett, J. 1985. Fathers and Daughters in Roman Society: Women and the Elite Family. Princeton, NJ: Princeton University Press.

Harder, A.-C. 20o8. Suavissima Soror. Untersuchungen zu den Bruder-SchwesterBeziehungen in der römischen Republik. Vestigia Band 8o. Munich: C. H. Beck.

Huebner, S. 2013. The Family in Roman Egypt: A Comparative Approach to Intergenerational Solidarity and Conflict. Cambridge: Cambridge University Press.

Johnston, S.I. 1999. Restless Dead: Encounters between the Living and the Dead in Ancient Greece. Berkeley: University of California Press.

Kajava, M. 1994. Roman Female Praenomina: Studies in the Nomenclature of Roman Women. Acta Instituti Romani Finlandiae 14. Rome: Institutum Romanum Finlandiae.

Kaster, R. 2005. Emotion, Restraint, and Community in Ancient Rome. Oxford: Oxford University Press.

Konstan, D. 2006. The Emotions of the Ancient Greeks. Toronto: University of Toronto Press.

Kropp, A. 2008. Defixiones: Ein aktuelles Corpus lateinischer Fluchtafeln. Spreyer: Kartoffeldruck-Verlag Kai Broderson.

Limberis, V. 1991. "The Eyes Infected by Evil: Basil of Caesarea's Homily, On Envy," HThR 84: 163-184. https://doi.org/10.1017/soo178160oooo8142. 


\section{PAULINE RipAT}

Mancini, G. 1923. "Scavi sotto la basilica di S. Sebastiano sull'Appia," NSA 20: 3-79.

Mander, J. 2013. Portraits of Children on Roman Funerary Monuments. Cambridge: Cambridge University Press.

Manioti, N. 2012. "All Female Family Bonds in Latin Epic." Ph.D. dissertation, Durham University.

McClain, T.D. 1998. "Redeeming Fabia: Sisters and Honor in Livy," AncW 29: 10-18.

McCreight, T. 2006. "Psyche's Sisters as Medicae? Allusions to Medicine in Cupid and Psyche," in W. H. Keulen, R. R. Nauta, and S. Panayotakis (eds.), Lectiones Scrupulosae: Essays on the Text and Interpretation of Apuleius' Metamorphoses in Honour of Maaike Zimmerman. Groningen: Barkhuis Publishing. 123-167.

McDermott, W.C. 1970. "The Sisters of P. Clodius," Phoenix 24: 39-47. https://doi. org/10.2307/1087402.

Neel, J. 2015. Legendary Rivals. Collegiality and Ambition in the Tales of Early Rome. Leiden: Brill.

Parkin, T. 2011. "The Roman Life Course and the Family," in B. Rawson (ed.), A Companion to Families in the Greek and Roman Worlds. Malden, MA: Wiley-Blackwell. 276-290.

Patera, M. 2014. Figures grecques de l'épouvante de l'antiquité au present: Peurs enfantines et adultes. Mnemosyne Supplement 376. Leiden: Brill.

Paule, M. T. 2014. "QVAE SAGA, QVIS MAGVS: On the Vocabulary of the Roman Witch," CQ 64: 745-757. https://doi.org/10.1017/sooo9838814000366.

Pomeroy, S. 1999. Plutarch's Advice to the Bride and Groom and a Consolation to His Wife: English Translations, Commentary, Interpretive Essays, and Bibliography. Oxford: Oxford University Press.

Rawson, B. (ed.). 2011. A Companion to Families in the Greek and Roman Worlds. Malden, MA/Oxford: Wiley-Blackwell.

Resnick, I. and K. Kitchell, Jr. 2007. “The Sweepings of Lamia': Transformations of the Myths of Lilith and Lamia," in A. Cuffel and B. Britt (eds.), Gender, Religion, and Culture in the Premodern World. New York: Palgrave Macmillan. 77-104.

Richlin, A. 2014. Arguments with Silence: Writing the History of Roman Women. Ann Arbor: University of Michigan Press.

Ripat, P. 2014. "Cheating Women: Curse Tablets and Roman Wives," in K. Stratton and D. Kalleres (eds.), Daughters of Hecate: Women and Magic in the Ancient World. Oxford/New York: Oxford University Press. 340-364.

—. 2016. "Roman Women, Wise Women, and Witches," Phoenix 70: 104-128. https://doi.org/10.7834/phoenix.70.1-2.0104.

Rosivach, V. 1994. "Anus: Some Older Women in Latin Literature," CW 88: 107-117. https://doi.org/10.2307/4351641.

Saller, R. 1994. Patriarchy, Property and Death in the Roman Family. Cambridge: Cambridge University Press.

— 1997. "Roman Kinship: Structure and Sentiment," in B. Rawson and P. Weaver (eds.), The Roman Family in Italy: Status, Sentiment, Space. Oxford: Oxford University Press. 7-34.

Smith, R. and S.H. Kim. 2007. "Comprehending Envy," Psychological Bulletin 133: 46-64. https://doi.org/10.1037/oo33-2909.133.1.46.

Späth, T. 2010. "Cicero, Tullia, and Marcus: Gender-Specific Concerns for Family Tradition?" in V. Dasen and T. Späth (eds.), Children, Memory, and Family Identity in Roman Culture. Oxford: Oxford University Press. 147-172.

Treggiari, S. 1991. Roman Marriage. Oxford: Oxford University Press.

Wiseman, T.P. 1995. Remus: A Roman Myth. Cambridge: Cambridge University Press. Zanker, P. 1990. The Power of Images in the Age of Augustus. Trans. A. Shapiro. Ann Arbor: University of Michigan Press. 